\title{
Macrophage Polarization in Physiological and Pathological Pregnancy
}

\author{
Yongli Yao, Xiang-Hong $X u^{*}$ and Liping Jin* \\ Clinical and Translational Research Center, Shanghai First Maternity and Infant Hospital, Tongji University School of Medicine, \\ Shanghai, China
}

The immunology of pregnancy is complex and poorly defined. During the complex process of pregnancy, macrophages secrete many cytokines/chemokines and play pivotal roles in the maintenance of maternal-fetal tolerance. Here, we summarized the current knowledge of macrophage polarization and the mechanisms involved in physiological or pathological pregnancy processes, including miscarriage, preeclampsia, and preterm birth. Although current evidence provides a compelling argument that macrophages are important in pregnancy, our understanding of the roles and mechanisms of macrophages in pregnancy is still rudimentary. Since macrophages exhibit functional plasticity, they may be ideal targets for therapeutic manipulation during pathological pregnancy. Additional studies are needed to better define the functions and mechanisms of various macrophage subsets in both normal and pathological pregnancy.

Keywords: macrophage, maternal-fetal interface, polarization, abortion, preeclampsia, preterm birth

\section{INTRODUCTION}

At the maternal-fetal interface, macrophages are the second largest group of cells and comprise $20-30 \%$ of all leukocytes (1). These cells display important roles in the pregnancy process as their plastic characteristics. Plastic characteristics refer to macrophage polarization, through which macrophages differentiate into specific phenotypes and have specific biological functions in response to microenvironmental stimuli. By simplified classification, macrophages have been divided into M1 and M2 subtypes based on their activation states (2). Actually, the properties of M1-like/M2-like macrophages are similar to those of Th1/Th2 cells (3). M1 macrophages are functionally pro-inflammatory and antimicrobial, while M2 macrophages are anti-inflammatory $(4,5)$.

At the maternal-fetal interface, both the number and proportion of M1/M2 macrophages are changed during different gestation periods to protect the fetus from the maternal immune microenvironment and establish foetomaternal tolerance. To sustain foetomaternal tolerance, more macrophages are polarized into alternatively activated (M2-like) macrophages, implying that the immunosuppressive properties of M2 macrophages are necessary for normal pregnancy. In abnormal pregnancy, more classically activated (M1) macrophages have been observed at the maternal-fetal interface. The balance of polarization between M1 and M2 macrophages is important for various processes of normal pregnancy, such as trophoblast invasion, spiral artery remodeling, and apoptotic cell phagocytosis. Conversely, the dysregulated polarization of macrophages was associated with inadequate remodeling of the uterine vessels and defective trophoblast invasion and finally led to spontaneous abortion, preeclampsia and preterm birth (6-8). 
Although increasing evidence has indicated the critical roles of macrophages in pregnancy-related diseases, the molecular mechanisms of dysregulated macrophage polarization are still poorly understood. Here, we summarize the current knowledge of macrophage polarization and the mechanisms involved in physiological or pathological pregnancy processes. A deeper understanding of the roles of macrophages in gestation might allow us to develop therapies to improve pregnancy outcomes.

\section{THE POLARIZATION OF MACROPHAGES}

\section{M1 and M2 Macrophages}

Macrophage polarization is crucial for tissue repairing and homeostasis maintenance (9). Macrophage polarization refers to the process by which macrophages produce distinct functional phenotypes as a reaction to specific microenvironmental stimuli and signals (3, 10-12). Macrophages can be polarized into classically activated (M1) and alternatively activated (M2) macrophages. M2 macrophages are divided into M2a, M2b, M2c, and M2d subcategories. These macrophages differ in their cell surface markers, secreted cytokines and biological functions. However, studies have indicated that the induction routes and regulated biological processes are complex interlacing network systems rather than simplistic schema (13). M1/M2 polarity arises from arginine metabolism via two antagonistic pathways: M1-like macrophages are the products of the iNOS pathway, which produces citrulline and NO from arginine, whereas M2like macrophages are the products of the arginase pathway, which produces ornithine and urea from arginine (14).

Following the activation by lipopolysaccharide (LPS) and Th1 cytokines (such as IFN- $\gamma$ and TNF- $\alpha$ ), macrophages are polarized into M1 macrophages and characterized by TLR-2, TLR-4, CD80, CD86, iNOS, and MHC-II surface phenotypes. These cells release various cytokines and chemokines (for example, TNF- $\alpha$, IL- $1 \alpha$, IL-1 $\beta$, IL-6, IL-12, CXCL9, and CXCL10) which exert positive feedback on unpolarized macrophages. That is, these factors attract more unpolarized macrophages to M1 state. Key transcription factors, such as NF-kB, STAT1, STAT5, IRF3, and IRF5 have been shown to regulate the expression of M1 genes. It seems that NF- $\mathrm{BB}$ and STAT1 are the two major pathways involved in M1 macrophage polarization and result in microbicidal and tumouricidal functions $(2,4,5,15,16)$.

M2 polarization occurs in response to downstream signals of cytokines such as IL-4, IL-13, IL-10, IL-33, and TGF- $\beta(5,16)$. Notably, only IL-4 and IL-13 directly induce M2 macrophage activation, whereas other cytokines (such as IL-33 and IL-25) amplify M2 macrophage activation by producing Th2 cytokines (17). M2 macrophages can be additionally identified by their expression of surface markers, such as mannitol receptor, CD206, CD163, CD209, FIZZ1, and Ym1/2. Up-regulation of cytokines and chemokines, such as IL-10, TGF- $\beta$, CCL1, CCL17, CCL18, CCL22, and CCL24 $(16,18)$ also attract unpolarized macrophages to polarize into the M2 state (19). Key transcription factors, such as STAT6, IRF4, JMJD3, PPAR $\delta$, and PPAR $\gamma$ have been shown to regulate the expression of M2 genes. Thus far, the STAT6 pathway has been considered to be the pathway to activate M2 macrophages (2). Macrophages contribute to the process of infection prevention, tissue repairing, angiogenesis and immunomodulation $(5,20)$. The main differences between M1 and M2 macrophages were shown in Figure 1.

\section{The Subsets of M2 Macrophages and Their Characteristics}

As mentioned above, M2 macrophages are subgrouped into M2a, M2b, M2c, and M2d. Activated by IL-4 or IL-13, M2a macrophages lead to the increased expression of IL-10, TGF$\beta$, CCL17, CCL18, and CCL22. These macrophages enhance the endocytic activity, promote cell growth and tissue repairing. M2b macrophages are activated by immune complex, Tolllike receptor (TLR) ligands and IL-1 $\beta$ and release both proand anti-inflammatory cytokines, such as TNF- $\alpha$, IL- $1 \beta$, IL6, and IL-10. Based on the expression profiles of cytokines and chemokines, M2b macrophages regulate the breadth and depth of immune responses and inflammatory reactions (21). M2c macrophages, also known as inactivated macrophages, are induced by glucocorticoids, IL-10 and TGF- $\beta$. These cells secrete IL-10, TGF- $\beta$, CCL16, and CCL18 and play crucial roles in the phagocytosis of apoptotic cells process $(12,22)$. Induced by the TLR antagonists, M2d macrophages lead to the release of IL-10 and vascular endothelial growth factors (VEGF) and promote angiogenesis and tumor progression (23). The characteristics of the M2 subtypes were summarized in Figure 2.

\section{The Common and Different Characteristics Between Macrophages and Dendritic Cells (DCs)}

Although both macrophages and DCs are members of the mononuclear phagocyte system, these cells are often considered distinct cell types based on their morphology and functions. Macrophages are defined as large vacuolar cells that are highly phagocytic and modulate immune responses by releasing various immune mediators, while DC are characterized as stellate migratory cells that act as sentinels in non-lymphoid tissues and migrate into lymphoid tissues upon antigen encounter, present antigen, and activate native T lymphocytes subsequently (24-26).

In vitro, macrophage colony-stimulating factor (M-CSF) induces the differentiation of monocytes into macrophages (27), while the combination of granulocyte/macrophage colonystimulating factor (GM-CSF) and interleukin 4 (IL4) induces the differentiation of monocytes into DCs (28). Macrophages are classified into 2 subgroups (M1 and M2 [M2a, M2b, M2c, M2d]) depending on their anti- or pro-inflammatory properties (29). DCs comprise two functionally distinct populations: plasmacytoid (pDC) and myeloid (mDC). mDCs have been further subdivided into 2 subsets based on their expression of BDCA3/CD141 (mDC1) and BDCA1/CD1c (mDC2) (30). Although macrophages and DCs originate from a common myeloid precursor, these cells are distinct cell types with individual and specific transcriptional profiles $(29,31-33)$. Of all the different cell characteristics, surface markers are often used to distinguish DCs from macrophages, but phenotypic analysis has considered as insufficient to define DC subsets, as there are some common phenotypic markers of the cells, such as F4/80, 


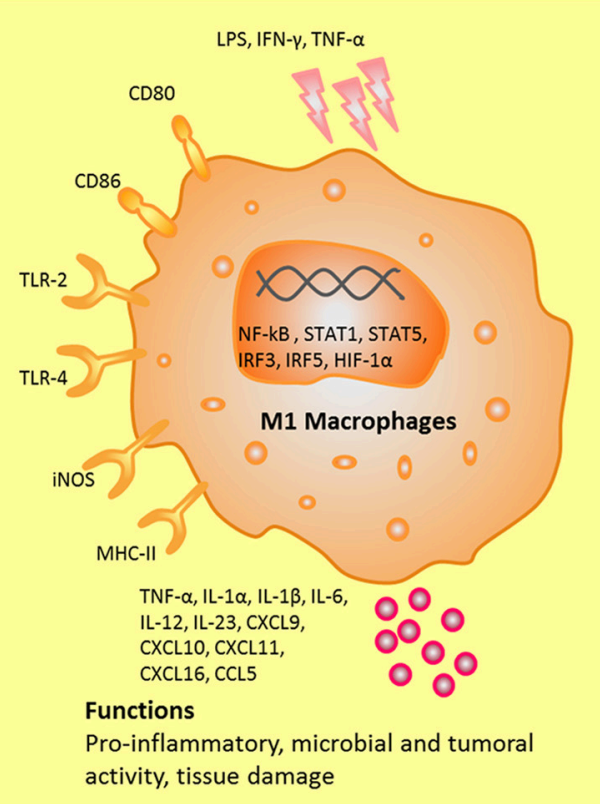

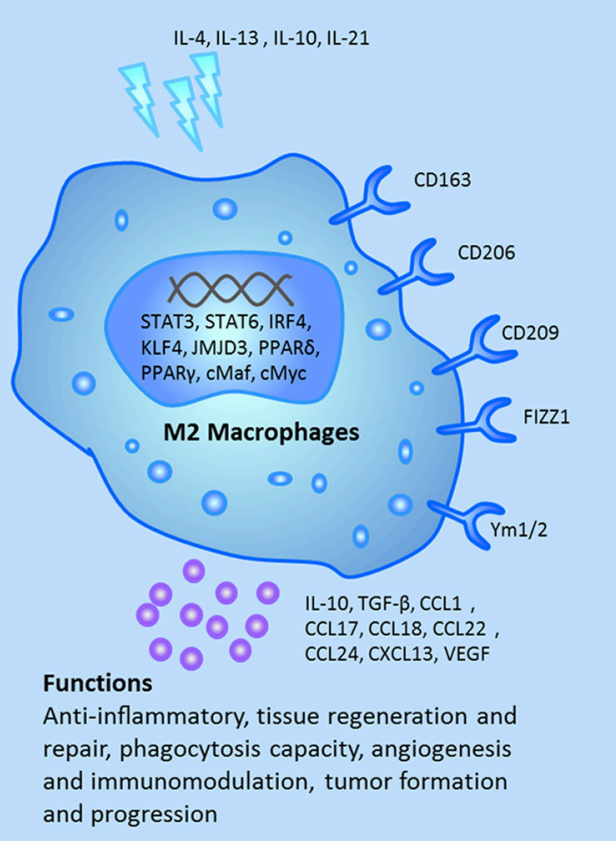

FIGURE 1 | The different stumili, surface markers, secreted cytokines, and biological functions between M1 and M2 macrophages were summarized. CCL, chemokine (C-C motif) ligand; cMaf, c-musculoaponeurotic fibrosarconna; CXCL, chemokine (C-X-C) ligand; FIZZ1, resistin-like $\alpha$; HIF, hypoxia inducible factor; iNOS, inducible nitric oxide synthase; IFN- $\gamma$, interferon-gamma; IL, interleukin; IRF, interferon regulatory factor; JMJD, Jumonji doman-containing protein; KLF, Kruppel-like factor; NF-кB, nuclear factor кB; KLF, Kruppel-like factor; LPS, lipopolysaccharides; MHC, major histocompatibility complex; PPAR, peroxisome proliferator-activated receptors; STAT, signal transducer and activator of transcription; TLR, Toll-like receptor; TNF- $\alpha$, tumor necrosis factor alpha; TGF- $\beta$, transforming growth factor beta; VEGF, vascular endothelial growth factor; Ym1, chitinase 3-like 3.

CD11b, CD11c, CD80, CD 86, CD163, CD209, and MHCII (34). These unspecific markers may result in the misinterpretation of DCs and macrophages. Here, we summarized the common and different characteristics between DCs and macrophages in Figure 3.

\section{THE ROLES OF MACROPHAGES IN NORMAL PREGNANCY}

\section{The Roles of M1 and M2 Macrophages in Normal Pregnancy}

Macrophages comprise approximately $20-30 \%$ of all human decidual leukocytes during pregnancy (35). A study on the classification of maternal-fetal macrophages was first performed in the Stein laboratory (36). Mills et al. divided macrophages into M1 and M2 subsets based on the consistency of the Th1/Th2 immune response and their pro-inflammation or anti-inflammation properties (37). Houser et al. divided decidual macrophages into CD11chigh and CD11c low subsets because the genes expressed in $\mathrm{CD} 11 \mathrm{c}^{\text {high }}$ decidual macrophages are associated with lipid metabolism and inflammation, whereas the genes expressed in CD11c low decidual macrophages are associated with extracellular matrix formation, muscle regulation, and tissue growth (38). In addition, some researchers have also categorized macrophages as CD209 ${ }^{\text {high }}$ and CD209- macrophages based on their differential CD209 expression levels (39). GM-CSF and M-CSF are two members of the CSF family, and these factors induce macrophages to polarize into M1-like and M2-like macrophages, respectively (14).

The polarization patterns of decidual macrophages vary with gestational age. During the peri-implantation period of gestation, macrophages polarize into M1 macrophages based on the fact that the ratio of M1/M2 macrophages in the uterus was 1.6 on the 1 st day and 1.45 on the 4 th day after female mice were inseminated. The a2V (a2 isoform of $\mathrm{V}$ ATPase)-mediated induction of CCL2 (MCP-1), which is a macrophage chemoattractant, promoted the recruitment of M1like macrophages during the peri-implantation period (40). When trophoblasts attach to the endometrial lining and invade the uterine stroma, decidual macrophages begin to transform to mixed M1/M2 profiles, and these mixed M1/M2 polarization patterns remain until mid-pregnancy. These macrophages are involved in extensive remodeling of the uterine vasculature, which is required to supply adequate placental-fetal blood (40, 41). After the placental development is completed, decidual macrophages shift toward a predominantly M2 phenotype, which promotes maternal immune tolerance to semiallogenic fetuses and protects fetal growth until parturition $(39,42)$. Although decidual macrophages show higher expression of M2 markers, such as CD206, CD163, and dendritic cell-specific ICAMgrabbing non-integrin (DC-sign) $(39,43,44)$, these cells do not 


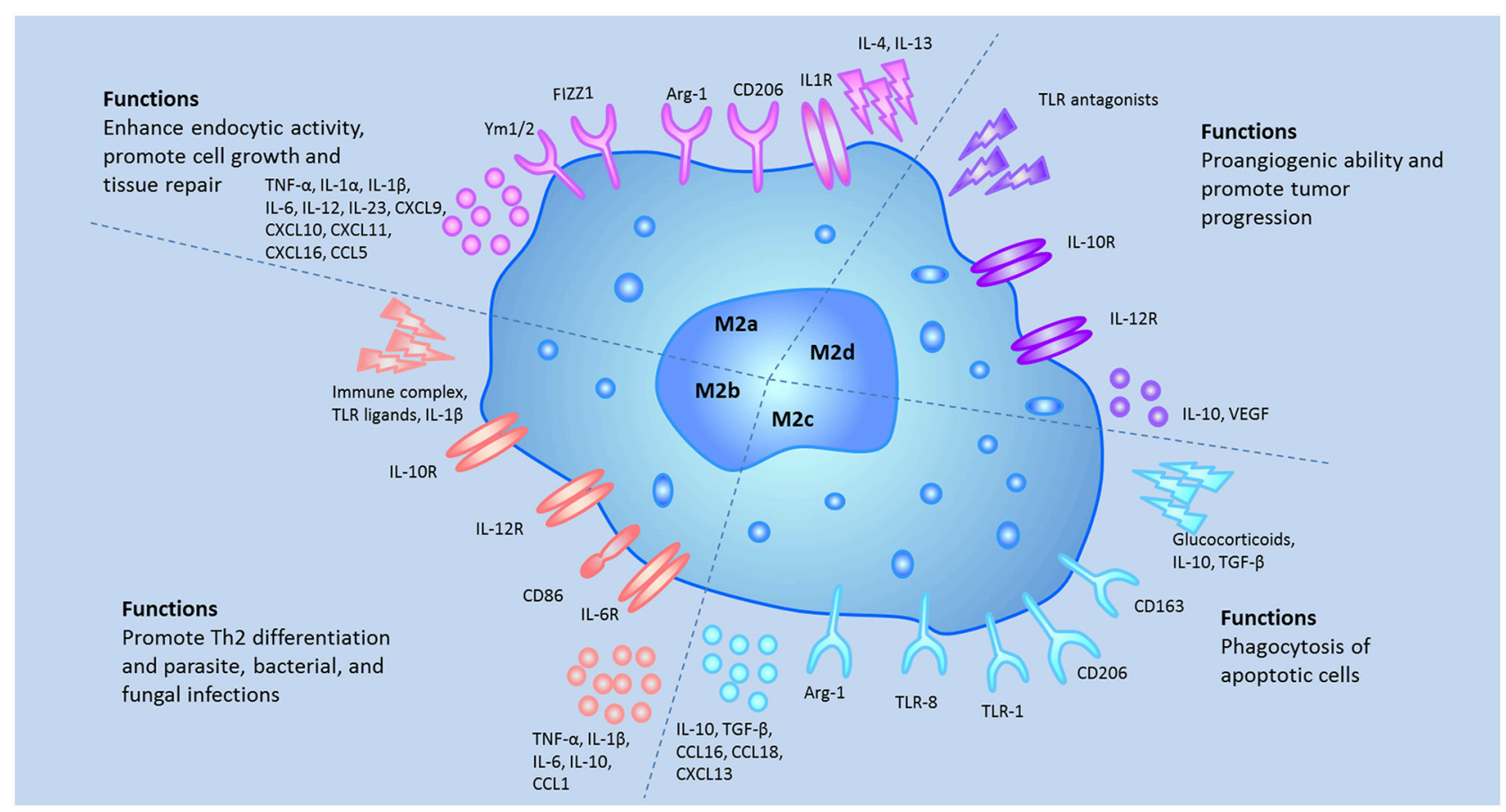

FIGURE 2 | The different stumili, surface markers, secreted cytokines, and biological functions of the M2 macrophage subsets were summarized.

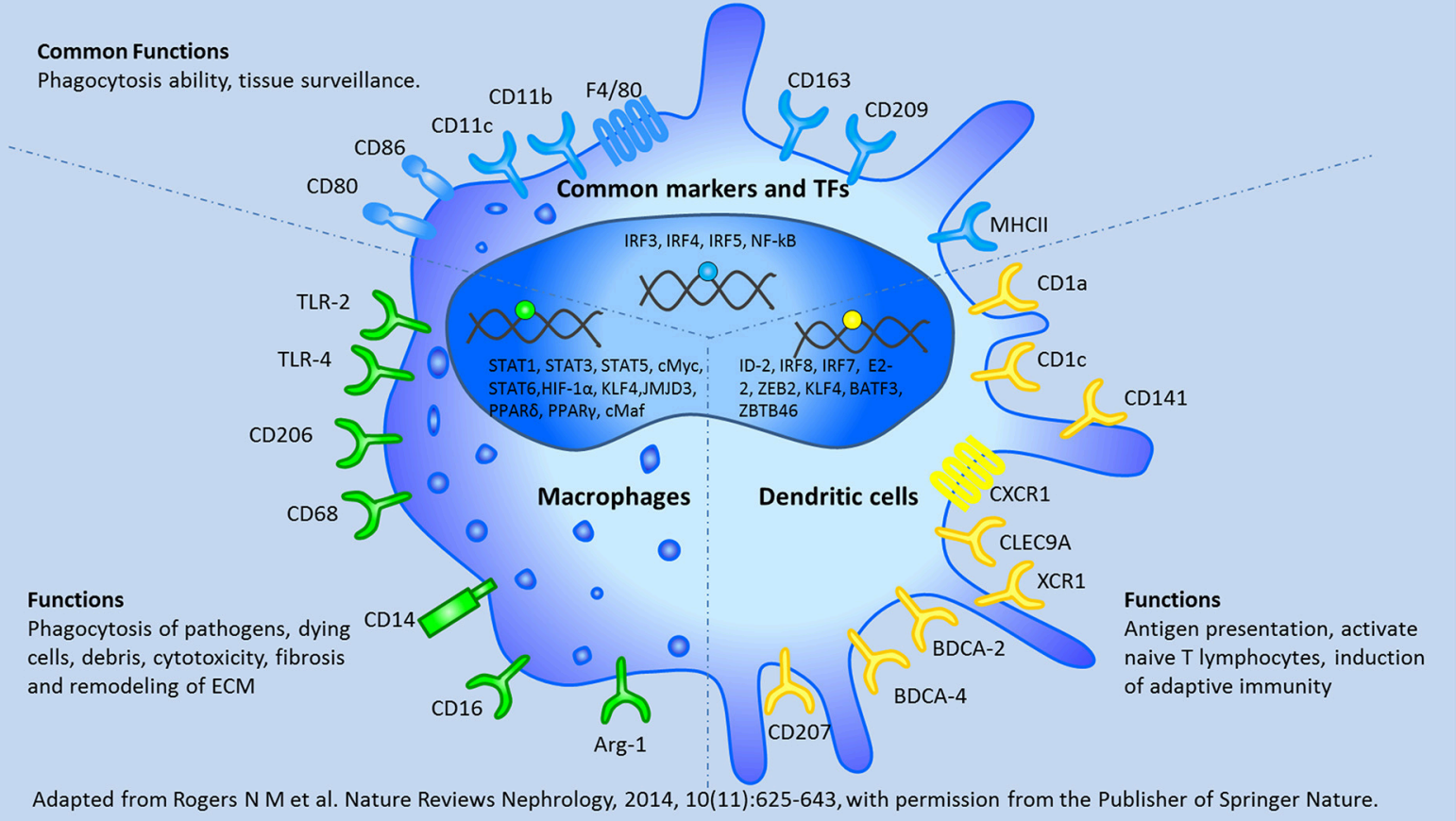

FIGURE 3 | The common and different characteristics between macrophages and dendritic cells were depicted according to their surface markers, transcription factors, and biological functions. BATF3, basic leucine zipper ATF-like transcription; BDCA, blood dendritic cells Ags; CLEC9A, C-type lectin 9A; E2-2, basic helix-loop-helix transcription factor; ID-2, inhibitor of DNA binding 2; XCR1, chemokine XC receptor 1; ZBTB46, zinc finger and BTB domain containing 46; ZEB2, Zinc finger $\mathrm{E}$ box-binding homeobox 2. Adapted from Rogers et al. (138) with permission from the publisher of Springer Nature. 
seem to be typical M2 macrophages, as they are induced by M-CSF and IL-10 rather than by Th2 cytokines, such as IL4 (39). At term labor, the number of M1 decidual macrophages is higher than that at term without labor (45), which suggests that pro-inflammatory macrophages may play important roles in the onset of term labor. Term decidual macrophages are involved in the initiation of labor because these cells have higher expression of CD80, CD86, CD83, HLA-DR, and CD16 and secrete higher IL-12 and lower IL-10 and TGF- $\beta$ levels than decidual macrophages from mid-pregnancy (46). A previous study observed that the concentration of IL- 6 was significantly higher than that of IL-10 in placental macrophages at term pregnancy (47). This observation is consistent with the findings of Osman I et al., showing that the mRNA expression of IL-6 is significantly higher during spontaneous labor in myometrium and cervical tissues than that in non-laboring tissues (48). Recently, some researchers have proposed a hypothetical model for labor. In this model, the increased levels of circulating cellfree fetal DNA activate the innate immune system by stimulating pattern-recognition receptor 9 (TLR9) in maternal macrophages and releasing a number of inflammatory cytokines, eventually triggering parturition (49).

\section{The Regulation Mechanisms of Macrophages in Normal Pregnancy}

During pregnancy, macrophages exist in the maternal-fetal interface. Macrophages play a positive role in embryo implantation, placental formation, embryonic development, and delivery processes. In all stages of pregnancy, the maternal uterus provides a microenvironment for embryo growth by producing various cytokines, promoting trophoblast cell invasion, remodeling of spiral arteries and phagocytose apoptotic cells (50-53) (Table 1).

\section{Trophoblast Invasion}

It was reported that decidual macrophages can inhibit NK cell-mediated lysis of human cytotrophoblasts (CTB) via TGF$\beta 1$ secretion (51). IL- $1 \beta$ secreted by activated macrophages facilitates trophoblast invasion by degrading the extracellular matrix. It has been shown that the enzymatic activity of matrix metalloproteinase (MMP)-9 and MMP-2 in trophoblastic cells is positively correlated with the concentration of $\operatorname{IL}-1 \beta(54,55)$. Immunoglobulin-like transcription factor inhibitory receptors, such as ILT2 and ILT4, can bind to HLA-G, which is highly expressed in extravillous trophoblast cells (EVT) (72). Recent work has also revealed that sHLAG5 can reduce the expression of CD86 and increase the expression of CD163. sHLAG5-polarized macrophages promote the secretion of IL- 6 and C-X-C motif ligand 1, which induce trophoblast invasion (56).

\section{Angiogenesis and Spiral Artery Remodeling}

Angiogenesis and spiral artery remodeling of the decidua are essential to ensure sufficient blood flow to the uterus and placenta during healthy pregnancy. A previous study has shown that macrophages are involved in the early stages of the decidual spiral artery remodeling process (67). It was reported that decidual macrophages regulate vascular remodeling by secreting vascular endothelial growth factor (VEGF), placental growth factor (PIGF) and their receptors fms-like tyrosine kinase (Flt-1) $(57,58)$. During the embryo implantation window, the expression of iNOS and VEGF in the endometrium of pregnant mice was significantly higher than that in pseudopregnant mice. The number of macrophages was correlated with the expression levels of iNOS and VEGF in the endometrium, implying that macrophages may be involved in vascular bed development before implantation by regulating the expression of iNOS and VEGF (59). Soluble fms-like tyrosine kinase-1 (sFlt-1) is a VEGF antagonist that inhibits angiogenesis (60). An in vivo study showed that the macrophage M2 phenotype has a higher angiogenic potential than other macrophage subsets in C57BL/6 J mice (73). Phosphorylation of protein kinase $\mathrm{C}(\mathrm{PKC})$ is necessary for the induced expression of VEGF in various cells $(74,75)$. GF109203X (a general PKC inhibitor) significantly decreased LPS-induced sFlt-1 secretion and significantly enhanced LPS-induced VEGF secretion in the murine macrophage RAW264.7 cell line compared with the LPS-only treated group (62). Pregnancy-specific glycoproteins (PSG) are members of the carcinoembryonic antigen family of immunoglobulin-like genes. They are highly homologous proteins secreted by the placenta and are the most abundant fetal proteins in the maternal blood at the end of pregnancy $(76,77)$. $\mathrm{Ha}$ et al. demonstrated that the expression levels of VEGFA were upregulated by PSG1 (the most abundant member of the human PSG family) both in a mouse macrophage cell line (RAW 264.7) and in human macrophages derived from blood monocytes (63). PSG22 (the most abundant PSG expressed during mouse early pregnancy) was found to upregulate the expression of VEGFA in mouse uterine macrophages (64). These findings suggest that PSG family members in macrophages may play important roles in vascular modifications. Further studies should elucidate the exact mechanisms for M2-induced angiogenesis.

\section{Phagocytose Apoptotic Cells}

Macrophages phagocytose apoptotic cells to promote trophoblast invasion and spiral artery remodeling and provide a balanced microenvironment at the maternal-fetal interface during the process of pregnancy (78). It has been proposed that apoptotic cells have immunosuppressive effects (79). When trophoblast debris were phagocytosed, the levels of pro-inflammatory cytokines, such as IL- $12, \mathrm{p} 70, \mathrm{IL}-1 \beta$ and IL- 8 , were significantly decreased, whereas the anti-inflammatory cytokines, such as IL-10, IL6, IL1Ra and IDO, were upregulated in macrophages $(65,66)$. Moreover, the decidual macrophages phagocytose vascular smooth muscle cells (VSMCs) to participate in spiral artery remodeling based on the fact that the expression levels of fractalkine and calreticulin were increased dramatically in VSMCs undergoing apoptosis $(67,68)$. Trophoblast-secreted factors, such as TGF- $\beta$, induce monocyte differentiation into M2-like macrophages and enhance the capacity of phagocytosis (69). sHLAG5-induced macrophages have also been shown to be polarized into an M2 phenotype with enhanced phagocytic activity (56). T-cell immunoglobulin and mucin domain protein 3 (Tim-3) is constitutively expressed on macrophages and is a receptor specialized for phosphatidylserine exposed on 
TABLE 1 | The regulation mechanisms of macrophages in normal pregnancy.

\begin{tabular}{|c|c|c|c|}
\hline & Samples & Mechanisms & References \\
\hline \multirow[t]{3}{*}{ Trophoblast invasion } & Human & $\begin{array}{l}\text { Decidual macrophages can inhibit NK cell-mediated lysis of CTB via TGF- } \beta 1 \\
\text { secretion; }\end{array}$ & $(51)$ \\
\hline & Human & $\begin{array}{l}\mathrm{IL}-1 \beta \text { facilitates trophoblast invasion by degrading the extracellular matrix, the } \\
\text { enzymatic activity of MMP-2, } 9 \text { is positively correlated with the level of IL-1 } \beta \text {; }\end{array}$ & $(54,55)$ \\
\hline & Human & $\begin{array}{l}\text { sHLAG5-polarized macrophages promote the secretion of IL-6 and C-X-C motif } \\
\text { ligand } 1 \text { to induce trophoblast invasion; }\end{array}$ & $(56)$ \\
\hline \multirow{7}{*}{$\begin{array}{l}\text { Angiogenesis and spiral } \\
\text { artery remodeling }\end{array}$} & Human & Decidual macrophages regulate vascular remodeling by secreting VEGF, PIGF, Flt-1; & $(57,58)$ \\
\hline & Mice & The expression of iNOS and VEGF is higher; & $(59)$ \\
\hline & Human & The sFlt-1 inhibits angiogenesis; & $(60)$ \\
\hline & THP1 cell line & VEGF promotes macrophages polarization into the M2 phenotype; & $(61)$ \\
\hline & RAW264.7 cell line & PKC inhibitor enhances the VEGF secretion and decreases the sFlt-1 secretion; & $(62)$ \\
\hline & $\begin{array}{l}\text { RAW264.7 cell line and } \\
\text { human }\end{array}$ & PSG1 upregulates the VEGFA secretion; & (63) \\
\hline & Mice & PSG22 upregulates the VEGFA secretion; & $(64)$ \\
\hline \multirow[t]{6}{*}{$\begin{array}{l}\text { Phagocytose apoptotic } \\
\text { cells }\end{array}$} & Human & $\begin{array}{l}\mathrm{IL}-12, \mathrm{p} 70, \mathrm{IL}-1 \beta, \mathrm{IL}-8 \text { are decreased, whereas IL-10, IL6, IL1Ra, IDO are } \\
\text { upregulated; }\end{array}$ & $(65,66)$ \\
\hline & Human & Fractalkine and calreticulin are increased in VSMCs; & $(67,68)$ \\
\hline & Human & $\begin{array}{l}\text { TGF } \beta \text { induces monocyte differentiation into M2-like macrophages and enhances the } \\
\text { capacity of phagocytosis; }\end{array}$ & (69) \\
\hline & Human & $\begin{array}{l}\text { sHLAG5-induced macrophages polarize into an M2 phenotype with enhanced } \\
\text { phagocytic activity; }\end{array}$ & $(56)$ \\
\hline & $\begin{array}{l}\text { Mice and RAW264.7 } \\
\text { cell line }\end{array}$ & $\begin{array}{l}\text { Tim-3 blocking antibodies cause macrophages failed to phagocytose apoptotic and } \\
\text { dying cells; }\end{array}$ & $(70)$ \\
\hline & Human & $\begin{array}{l}\text { Decidual macrophages secrete IL-1 } 1 \beta \text { and TNF- } \alpha \text { to induce M-CSF expression, which } \\
\text { initiates caspase-dependent EVT apoptosis. }\end{array}$ & $(71)$ \\
\hline
\end{tabular}

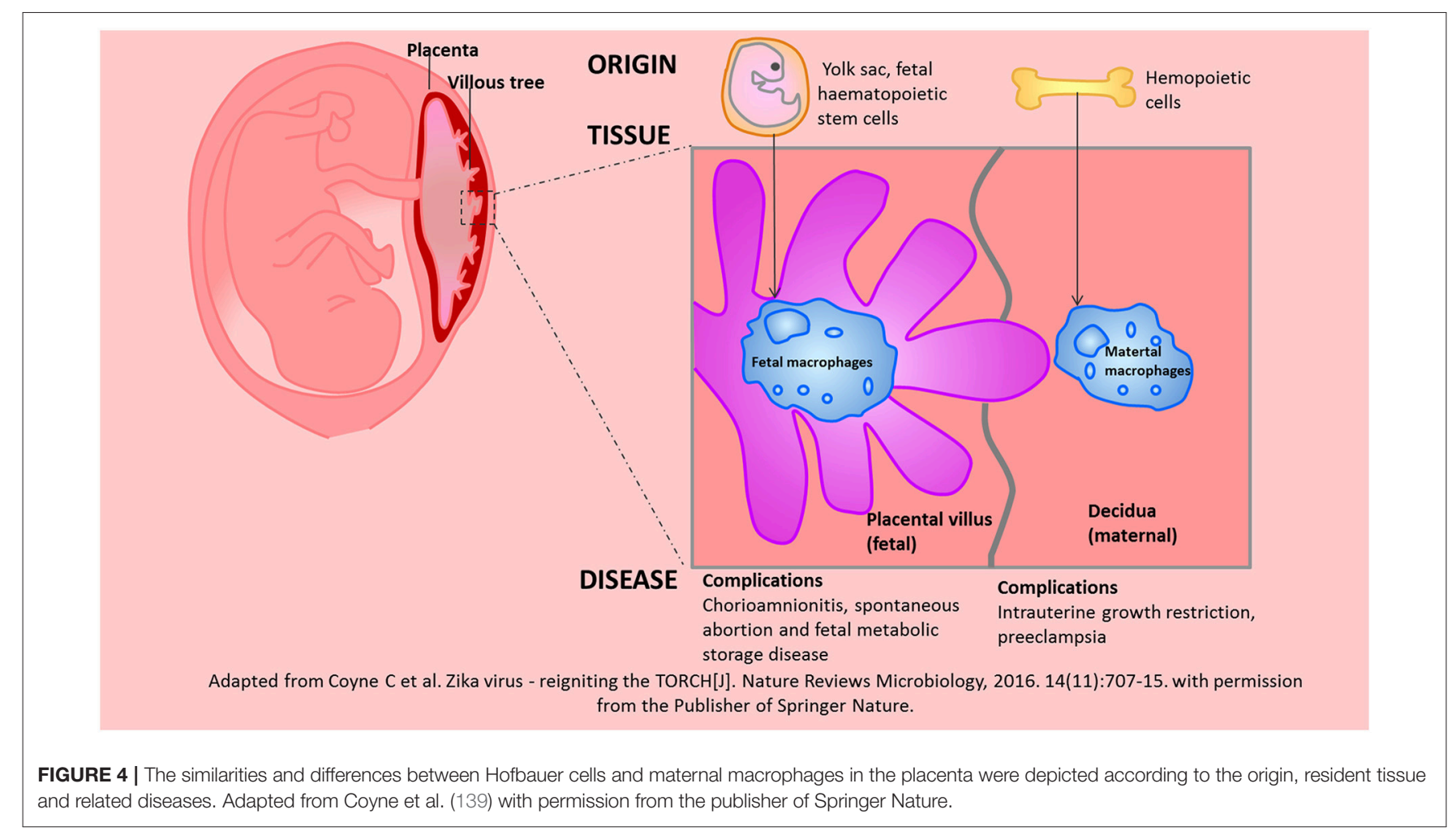


the surface of apoptotic cells (80). Treating pregnant mice with Tim-3 blocking antibodies caused the failure of uterine macrophages in mice to phagocytose apoptotic and dying cells. Thus, Tim-3 was considered to play a significant role in the process of phagocytose apoptotic cells and dying cells by macrophages (70). Decidual macrophages secrete various pro-infammatory cytokines (such as IL-1 $\beta$ and TNF- $\alpha$ ) to induce M-CSF expression, which initiates caspase-dependent EVT apoptosis (71).

\section{The Roles of "Hofbauer Cells" in Normal Pregnancy}

Hofbauer cells refers to fetal placental macrophages within the chorionic villi (81). Hofbauer cells have different origins at different stages of pregnancy. At the early stages of pregnancy, Hofbauer cells may originate from villous mesenchymal stem stromal cells or monocyte progenitor cells from the hypoblastderived yolk sac; at later stages of pregnancy, Hofbauer cells may originate from fetal haematopoietic stem cells (82-84). Yolk sacderived macrophages may participate in the tissue development and morphogenesis processes, while haematopoietic stem cellderived macrophages may be important for haematopoiesis and antigen presentation processes.

Hofbauer cells have been found to play critical roles in maternal-fetal immune tolerance since the 1990s. Bockle found that Hofbauer cells highly express CD163 and DC-SIGN/CD209 in the term placenta. Thus, Hofbauer cells have been suggested to be M2 macrophages (85). However, CD163, DC-SIGN, and CD206 (M2 markers) were not clearly detected in the term placenta in the study by Joerink et al. whereas CX3CR1, IL7R or CCR7 (M1 markers) were observed in the term placenta (86). Studies have also shown that Hofbauer cells are positive for CD209 (M2a marker), CD86 (M2b marker), HLA-DR (M2a/M2b marker), CD206 (M2a/M2c), and CD14 (M2c marker) (82). Recently, Kim SY et al. demonstrated that the genes encoding markers of M1 macrophages, such as TLR9, IL1B, IL12RB2, CD48, and FGR, were hypermethylated in Hofbauer cells, whereas the genes encoding markers of M2 macrophages, such as CCL2, CCL13, CCL14, CD209 and A2M, were hypomethylated in Hofbauer cells (87). Hofbauer cells may promote placental angiogenesis, chorionic villus growth, and stromal fluid balance, absorb immune complexes and function as antigen presenting cells (88). Perturbed Hofbauer cells function is a common occurrence in chorioamnionitis, spontaneous abortion and fetal metabolic storage disease. Although both of Hofbauer cells and maternal macrophages are predominantly M2 phenotypes, they have different origins, resident tissues, biological functions, and associated complications. We depicted these differences in the Figure 4.

\section{THE ROLES OF MACROPHAGES IN PREGNANCY COMPLICATIONS}

\section{The Roles of Macrophages in Miscarriage}

Miscarriage, especially recurrent spontaneous miscarriage, is an immune-related reproductive disorder (89). The WHO defines 3 or more consecutive miscarriages before the 20th week of gestation as recurrent miscarriage (90). The definition from American College of Obstetricians and Gynecologists is "just 2 consecutive miscarriages" (91). The study on human decidual tissues reported that the number of $\mathrm{CD}^{+} 8^{+}$macrophages is higher in recurrent miscarriage patients than in artificial abortions patients (92). Similarly, it has also been observed that macrophage depletion could rescue CpG ODN (CpGOligodeoxynucleotides)-induced fetal resorption in the $\mathrm{CBA} / \mathrm{J}$ $\mathrm{x}$ DBA/2 mice model (93). Cathepsins belong to the family of lysosomal cysteine proteases and play important roles in the degradation of matrix molecules and intracellular proteolysis. It has been shown that the expression of cathepsin $\mathrm{B}, \mathrm{D}, \mathrm{H}$ was upregulated and cathepsin $\mathrm{E}$ was downregulated in the decidual tissues of spontaneous miscarriage patients compared to normal pregnancy patients (94). Cathepsin-deficient $\left(\mathrm{CatE}^{-/-}\right)$mice were fertile, but the litter sizes were smaller than those of wildtype mice (95). The percentage of FasL ${ }^{+} / \mathrm{CD} 8^{+}$cells is increased in spontaneous abortion patients compared to normal pregnancy subjects. These results implied that Fas/FasL mediated apoptosis of macrophages involved in the occurrence of abortion (6).

Macrophages are skewed toward the M1 phenotypes in spontaneous abortion (96). The ratio of M1/M2 on day 16 was $3.9-4.2$ in the abortion-prone mice, while the number was 1.21.6 on both day 12 or 16 in the non-abortion-prone mice (97). In decidual macrophages from patients with spontaneous abortion, the expression levels of CD80, IL-12, and IL-13 were increased, while the expression levels of CD163, CD206, IL-10, and ARG-1 were decreased $(98,99)$. PPAR $\gamma$ is essential for the differentiation of alternatively activated (M2) macrophages (100). PPAR $\gamma$ was

TABLE 2 | The roles of macrophages in miscarriage.

\begin{tabular}{|c|c|c|}
\hline Samples & Mechanisms & References \\
\hline Human & Cathepsin B, D, H are upregulated and cathepsin E is downregulated in the decidual tissues; & (94) \\
\hline Mice & The litter sizes of CatE $^{-/-}$mice are smaller; & (95) \\
\hline Mice & The Fas/FasL mediated apoptosis is increased; & (6) \\
\hline Human & CD80, IL-12, IL-13 are increased, while CD163, CD206, IL-10, ARG-1 are decreased; & $(98,99)$ \\
\hline Human & Reduced the expression of PPAR $\gamma$ may skew macrophages to the M1 phenotype; & $(101)$ \\
\hline Human and U937 cell line & $\begin{array}{l}\text { Dysregulation of the IL-33/ST2 signaling pathway may skew macrophages into the M1 } \\
\text { phenotype; }\end{array}$ & $(103)$ \\
\hline Human and mice & $\begin{array}{l}\text { The decreased expression of RANKL could switch macrophages into M1 phenotype through } \\
\text { the Akt/STAT6-Jmjd3/IRF4 signaling pathway. }\end{array}$ & $(104)$ \\
\hline
\end{tabular}


TABLE 3 | The roles of macrophages in preeclampsia.

\begin{tabular}{|c|c|c|}
\hline Samples & Mechanisms & References \\
\hline Human & TNF- $\alpha, I L-6$ and IL-8 are increased, IL-10 is decreased; & $(114)$ \\
\hline Human & Amniotic MSCs could skew macrophages toward a M2 phenotype; & $(119)$ \\
\hline Human & $\begin{array}{l}\text { TGF- } \beta 3 \text { promotes the expression of miR-494 in dMSCs and downregulates the effect of dMSCs switching the } \\
\text { macrophages toward a M2 phonetype; }\end{array}$ & $(117)$ \\
\hline Human & Macrophages produce TNF- $\alpha$ and IFN- $\gamma$ to affect trophoblast invasion by the reconstitution of the ECM; & $(120,121)$ \\
\hline Human & $\begin{array}{l}\text { TNF- } \alpha \text { increases the expression of MMP-1, 3, } 9 \text { by activating p38 MAPK phosphorylation in decidual cells, } \\
\text { whereas IFN- } \gamma \text { blocked TNF- } \alpha \text {-induced p38 phosphorylation to protect against MMP-mediated ECM degradation. }\end{array}$ & $(122)$ \\
\hline Human & TNF- $\alpha$ and IFN- $\gamma$ increase the sensitivity of trophoblast cells to apoptosis; & $(111,123)$ \\
\hline Human & TNF- $\alpha$ and IFN- $\gamma$ increase the XIAP expression and initiate the caspase-dependent pathway; & $(124)$ \\
\hline Rats & $\begin{array}{l}\text { More activated macrophages and impaired spiral artery remodeling are observed in the mesometrial triangle of the } \\
\text { ATP-infused rats. }\end{array}$ & $(127)$ \\
\hline
\end{tabular}

TABLE 4 | The roles of macrophages in preterm birth.

\begin{tabular}{|c|c|c|}
\hline Samples & Mechanisms & References \\
\hline Mice & Macrophages induce the release of MMPs and collagen degradation in the cervix; & $(133)$ \\
\hline Mice & $\begin{array}{l}\text { Progesterone decreases the expression of } \mathrm{C} 5 \mathrm{aR} \text { and then inhibits the release of MMP-9 to } \\
\text { protect against the PTL; }\end{array}$ & (8) \\
\hline Mice & HCG stimulates the production of progesterone and prevents endotoxin-induced PTL; & $(134)$ \\
\hline Mice & $\begin{array}{l}\text { Macrophages polarize into the M1 subtype by activating the Notch signaling pathway, which } \\
\text { could be blocked by a2V; }\end{array}$ & $(137)$ \\
\hline Human and mice & $\begin{array}{l}\text { The activation of PPAR } \gamma \text { attenuates the macrophage-mediated pro-inflammatory response and } \\
\text { prevents PTL. }\end{array}$ & $(45)$ \\
\hline
\end{tabular}

significantly downregulated in placental tissues from women with recurrent miscarriages. This implies that downregulation of PPAR $\gamma$ expression may skew macrophages to the M1 phenotype and lead to miscarriages (101). IL-33, a member of the IL-1 family, induced the proliferation of cytotrophoblasts (CTB) and triggered the migration of EVT by interacting with the IL-33 ligand ST2L (102). Dysregulation of the IL-33/ST2 signaling pathway may skew normal pregnancy-derived $\mathrm{dM} \phi$ s and U937 cells into the M1 phenotype (103). Meng et al. observed that the levels of RANKL/RANK were reduced in villi and decidua from miscarriage patients compared to those from normal pregnancy patients. Downregulation of nuclear factor- $\kappa$ B ligand (RANKL) caused murine fetal loss. The abnormal expression of RANKL may switch macrophages into M1 phenotype through the Akt/STAT6-Jmjd3/IRF4 signaling pathway (104) (Table 2).

\section{The Role of Macrophages in Preeclampsia}

Preeclampsia, a pregnancy-specific disorder characterized by hypertension in combination with proteinuria, occurs at 20 weeks after gestation (105). With a prevalence of $6-8 \%$ of pregnancies, preeclampsia is a major cause of maternal and fetal morbidity and mortality (106). The pathophysiological mechanism of preeclampsia has not been elucidated in detail; however, preeclampsia is associated with impaired spiral artery remodeling and with changes in the numbers of trophoblasts and immune cells in the placenta. Decreased numbers of decidual macrophages were reported in patients with preeclampsia $(107,108)$. However, various studies have found increased numbers of macrophages in the placenta of patients with preeclampsia (109-111). Conflicting findings across studies may be due to the use of different cell makers or methodologies and different locations of the placenta being studied.

The numbers of macrophages were changed in preeclamptic patients, and the polarization states of macrophages were different in preeclamptic patients compared to normal pregnancy patients. A decreased number of M2 macrophages and an increased number of M1 macrophages in the placenta may be related to preeclampsia $(112,113)$. This finding is in concordance with an increase in pro-inflammatory cytokines (such as TNF- $\alpha$, IL-6, and IL-8) and a decrease in antiinflammatory cytokines (such as IL-10) in the placenta of preeclamptic patients (114). Various tissue-derived mesenchymal stem cells (MSCs) regulate the polarization of macrophages (115-118). Human placental MSCs can shift macrophages from an M1-like to an M2-like phenotype (115). In line with this finding, human amniotic MSCs have anti-inflammatory properties and skew macrophages toward a M2 phenotype (119). In patients with preeclampsia, TGF- $\beta 3$ in decidua could promote the expression of miR-494 in dMSCs and downregulate the effect of dMSCs switching the macrophages toward M2 phonetype (117).

The altered amount and polarization phenotypes of uterine macrophages may account for the defective trophoblast invasion and spiral artery remodeling observed in preeclampsia. Aberrantly activated macrophages are capable of producing various molecules (such as TNF- $\alpha$ and IFN- $\gamma$ ) that may affect trophoblast invasion by the reconstitution of the extracellular 
matrix (ECM) $(120,121)$. Lockwood CJ et al. demonstrated that TNF- $\alpha$ bound to TNF- $\alpha$ R and caused the increased expression of MMP-1, MMP-3, and MMP-9 by activating p38 MAPK phosphorylation in decidual cells, whereas IFN- $\gamma$ bound to IFN- $\gamma \mathrm{R}$ and blocked TNF- $\alpha$-induced p38 phosphorylation to protect against MMP-mediated ECM degradation (122). There is evidence that placental apoptosis was increased in preeclampsia. The elevated levels of pro-inflammatory cytokines secreted by aberrantly activated macrophages (such as TNF- $\alpha$ and IFN- $\gamma$ ) may increase the sensitivity of trophoblast cells to apoptosis and restrict trophoblast invasion $(111,123)$. TNF- $\alpha$ and IFN- $\gamma$ have been shown to increase the expression of the pro-apoptotic factor X-linked inhibitor of apoptosis (XIAP) in trophoblast cells and initiate the caspase-dependent pathway (124). Deficient spiral artery remodeling is hypothesized to account for the major pathogenesis of early-onset preeclampsia (125). It has been proven that macrophages were associated with impaired spiral artery remodeling in patients with preeclampsia (126). In addition, it has been speculated that ATP-induced activated macrophages may prevent spiral artery remodeling in preeclampsia based on the fact that more activated macrophages were observed in the mesometrial triangle of ATP-infused rats, and spiral artery remodeling in the rat mesometrial triangle was impaired (127) (Table 3).

\section{The Role of Macrophages in Preterm Birth}

Preterm birth, the birth of a baby at fewer than 37 weeks of gestational age (128), is the most common cause of death among infants worldwide (129). Inflammation has been considered to be associated with preterm birth (130). An increased number of macrophages have been observed in the cervix of women in preterm labor (131). Studies have been reported that the depletion of $\mathrm{F} / 80^{+}$macrophages could rescue the CpGinduced preterm birth of mice to term (132). Studies have shown that macrophages induce the release of MMPs and collagen degradation in the cervix of mice that deliver at preterm (133). The interaction of C5a, a chemotactic factor and activator of macrophages, with $\mathrm{C} 5 \mathrm{aR}$ is necessary for macrophages to release MMP-9 and to be involved in the cervical remodeling process. Progesterone was reported to decrease the expression of $\mathrm{C} 5 \mathrm{aR}$ and inhibit preterm birth in mice (8). Human chorionic gonadotropin (HCG) has been confirmed to stimulate progesterone production (134), thus having anti-infammatory capacity and preventing endotoxininduced preterm birth in mice. The numbers of M1 macrophages in decidual tissue from spontaneous preterm labor patients were much greater than those in term without labor patients. Studies have also proposed that both M1 $\left(\mathrm{CD} 11 \mathrm{c}^{+}\right)$and

\section{REFERENCES}

1. Williams PJ, Searle RF, Robson SC, Innes BA, Bulmer JN. Decidual leucocyte populations in early to late gestation normal human pregnancy. J Reprod Immunol. (2009) 82:24-31. doi: 10.1016/j.jri.2009.08.001

2. Murray PJ. Macrophage polarization. Annu Rev Physiol. (2017) 79:541-66. doi: 10.1146/annurev-physiol-022516-034339
M2 (CD206) macrophages participate in preterm birth since the expression levels of both pro-inflammatory (IL-6, IFN$\gamma$ ) and anti-inflammatory cytokines (IL-10) were significantly increased in the uterus of PGN+poly (I:C)-treated preterm labor mice (135). The Notch signaling pathway has been considered to promote the M1 polarization of macrophages (136). During inflammation-induced preterm labor in mice, decidual macrophages were polarized into the M1 subtype by activating the Notch signaling pathway, which could be blocked by a2V (137). Xu Y et al. demonstrated that decidual M1like macrophages were associated with spontaneous preterm labor patients. The activation of PPAR $\gamma$ via rosiglitazone could attenuate the macrophage-mediated pro-inflammatory response and prevent preterm birth in mice (45) (Table 4).

\section{CONCLUSIONS}

Altogether, this review summarized the current knowledge of the polarization of macrophages and their regulatory mechanisms at different stages of pregnancy, as well as the roles of these cells in pathological processes. Although current evidence provides a compelling argument that macrophages are important in pregnancy, our understanding of the roles and mechanisms of macrophages in pregnancy is still rudimentary. Since macrophages exhibit functional plasticity, they may be ideal targets for therapeutic manipulation during pathological pregnancy. Additional studies are needed to better define the functions and mechanisms of various macrophage subsets in both normal and pathological pregnancy.

\section{AUTHOR CONTRIBUTIONS}

All authors listed have made a substantial, direct and intellectual contribution to the work, and approved it for publication.

\section{FUNDING}

This study was supported by the Key Program of the National Natural Science Foundation of China (81730039), the National Natural Science Foundation of China (81671460), the National Key Research and Development Program of China (2017YFC1001401), Shanghai Municipal Medical and Health Discipline Construction Projects (2017ZZ02015), the National Basic Research Program of China (2015CB943300), the Program for Shanghai leaders, and the Program of Shanghai Outstanding Academic Leaders (15XD1500900).

3. Mantovani A, Sica A, Sozzani S, Allavena P, Vecchi A, Locati M. The chemokine system in diverse forms of macrophage activation and polarization. Trends Immunol. (2004) 25:677-86. doi: 10.1016/j.it.2004.09.015

4. Weisser SB, McLarren KW, Kuroda E, Sly LM. Generation and characterization of murine alternatively activated macrophages. Methods Mol Biol. (2013) 946:225-39. doi: 10.1007/978-1-62703-128-8_14 
5. Porta C, Riboldi E, Ippolito A, Sica A. Molecular and epigenetic basis of macrophage polarized activation. Semin Immunol. (2015) 27:237-48. doi: 10.1016/j.smim.2015.10.003

6. Guenther S, Vrekoussis T, Heublein S, Bayer B, Anz D, Knabl J, et al. Decidual macrophages are significantly increased in spontaneous miscarriages and over-express FasL: a potential role for macrophages in trophoblast apoptosis. Int J Mol Sci. (2012) 13:9069-80. doi: 10.3390/ijms13079069

7. Schonkeren D, van der Hoorn ML, Khedoe P, Swings G, van Beelen E, Claas F, et al. Differential distribution and phenotype of decidual macrophages in preeclamptic versus control pregnancies. Am J Pathol. (2011) 178:709-17. doi: 10.1016/j.ajpath.2010.10.011

8. Gonzalez JM, Franzke C-W, Yang F, Romero R, Girardi G. Complement activation triggers metalloproteinases release inducing cervical remodeling and preterm birth in mice. Am J Pathol. (2011) 179:838-49. doi: 10.1016/j.ajpath.2011.04.024

9. Patel U, Rajasingh S, Samanta S, Cao T, Dawn B, Rajasingh J. Macrophage polarization in response to epigenetic modifiers during infection and inflammation. Drug Discov Today. (2017) 22:186-93. doi: 10.1016/j.drudis.2016.08.006

10. Canton J. Phagosome maturation in polarized macrophages. J Leukoc Biol. (2014) 96:729-38. doi: 10.1189/jlb.1MR0114-021R

11. Sica A, Mantovani A. Macrophage plasticity and polarization: in vivo veritas. J Clin Invest. (2012) 122:787-95. doi: 10.1172/jci59643

12. Chistiakov DA, Bobryshev YV, Nikiforov NG, Elizova NV, Sobenin IA, Orekhov AN. Macrophage phenotypic plasticity in atherosclerosis: the associated features and the peculiarities of the expression of inflammatory genes. Int J Cardiol. (2015) 184:436-45. doi: 10.1016/j.ijcard.2015.03.055

13. Atri C, Guerfali FZ, Laouini D. Role of human macrophage polarization in inflammation during infectious diseases. Int J Mol Sci. (2018) 19:1801. doi: $10.3390 /$ ijms 19061801

14. Lampiasi N, Russo R, Zito F. The alternative faces of macrophage generate osteoclasts. Biomed Res Int. (2016) 2016:9089610. doi: 10.1155/2016/ 9089610

15. Martinez FO, Gordon S. The M1 and M2 paradigm of macrophage activation: time for reassessment. F1000Prime Rep. (2014) 6:13. doi: $10.12703 / \mathrm{p} 6-13$

16. Wang $\mathrm{N}$, Liang $\mathrm{H}$, Zen $\mathrm{K}$. Molecular mechanisms that influence the macrophage m1-m2 polarization balance. Front Immunol. (2014) 5:614. doi: 10.3389/fimmu.2014.00614

17. O'Shea JJ, Paul WE. Mechanisms underlying lineage commitment and plasticity of helper CD4+ T cells. Science. (2010) 327:1098-102. doi: $10.1126 /$ science 1178334

18. Gordon S, Martinez FO. Alternative activation of macrophages: mechanism and functions. Immunity. (2010) 32:593-604. doi: 10.1016/j.immuni.2010.05.007

19. Mulder R, Banete A, Basta S. Spleen-derived macrophages are readily polarized into classically activated (M1) or alternatively activated (M2) states. Immunobiology. (2014) 219:737-45. doi: 10.1016/j.imbio.2014.05.005

20. Mantovani A, Biswas SK, Galdiero MR, Sica A, Locati M. Macrophage plasticity and polarization in tissue repair and remodelling. J Pathol. (2013) 229:176-85. doi: 10.1002/path.4133

21. Wang LX, Zhang SX, Wu HJ, Rong XL, Guo J. M2b macrophage polarization and its roles in diseases. J Leukoc Biol. (2018) 1-14. doi: 10.1002/jlb.3ru1018-378rr

22. Zizzo G, Hilliard BA, Monestier M, Cohen PL. Efficient clearance of early apoptotic cells by human macrophages requires M2c polarization and MerTK induction. J Immunol. (2012) 189:3508-20. doi: 10.4049/jimmunol.1200662

23. Ferrante CJ, Pinhal-Enfield G, Elson G, Cronstein BN, Hasko G, Outram S, et al. The adenosine-dependent angiogenic switch of macrophages to an M2like phenotype is independent of interleukin-4 receptor alpha (IL-4Ralpha) signaling. Inflammation. (2013) 36:921-31. doi: 10.1007/s10753-013-9621-3

24. Schlitzer A, Sivakamasundari V, Chen J, Sumatoh HR, Schreuder J, Lum J, et al. Identification of $\mathrm{CDC} 1$ - and $\mathrm{cDC} 2$-committed DC progenitors reveals early lineage priming at the common DC progenitor stage in the bone marrow. Nat Immunol. (2015) 16:718-28. doi: 10.1038/ni.3200

25. Collin M, McGovern N, Haniffa M. Human dendritic cell subsets. Immunology. (2013) 140:22-30. doi: 10.1111/imm.12117
26. Gordon S, Pluddemann A. Tissue macrophages: heterogeneity and functions. BMC Biol. (2017) 15:53. doi: 10.1186/s12915-017-0392-4

27. Jin $X$, Kruth HS. Culture of macrophage colony-stimulating factor differentiated human monocyte-derived macrophages. J Vis Exp. (2016) e54244. doi: 10.3791/54244

28. Sallusto F, Lanzavecchia A. Efficient presentation of soluble antigen by cultured human dendritic cells is maintained by granulocyte/macrophage colony-stimulating factor plus interleukin 4 and downregulated by tumor necrosis factor alpha. J Exp Med. (1994) 179:1109-18. doi: 10.1084/jem.179.4.1109

29. Shapouri-Moghaddam A, Mohammadian S, Vazini H, Taghadosi M, Esmaeili SA, Mardani F, et al. Macrophage plasticity, polarization, and function in health and disease. J Cell Physiol. (2018) 233:6425-40. doi: $10.1002 /$ jcp.26429

30. Macri C, Pang ES, Patton T, O’Keeffe M. Dendritic cell subsets. Semin Cell Dev Biol. (2018) 84:11-21. doi: 10.1016/j.semcdb.2017.12.009

31. Obregon C, Kumar R, Pascual MA, Vassalli G, Golshayan D. Update on dendritic cell-induced immunological and clinical tolerance. Front Immunol. (2017) 8:1514. doi: 10.3389/fimmu.2017.01514

32. Colin S, Chinetti-Gbaguidi G, Staels B. Macrophage phenotypes in atherosclerosis. Immunol Rev. (2014) 262:153-66. doi: 10.1111/imr.12218

33. Collin M, Bigley V. Human dendritic cell subsets: an update. Immunology. (2018) 154:3-20. doi: 10.1111/imm.12888

34. Sozzani S, Del Prete A, Bosisio D. Dendritic cell recruitment and activation in autoimmunity. J Autoimmun. (2017) 85:126-40. doi: 10.1016/j.jaut.2017.07.012

35. Liu S, Diao L, Huang C, Li Y, Zeng Y, Kwak-Kim JYH. The role of decidual immune cells on human pregnancy. J Reprod Immunol. (2017) 124:44-53. doi: 10.1016/j.jri.2017.10.045

36. Stein M, Keshav S, Harris N, Gordon S. Interleukin 4 potently enhances murine macrophage mannose receptor activity: a marker of alternative immunologic macrophage activation. J Exp Med. (1992) 176:287-92. doi: 10.1084/jem.176.1.287

37. Mills CD, Kincaid K, Alt JM, Heilman MJ, Hill AM. M-1/M-2 macrophages and the Th1/Th2 paradigm. J Immunol. (2000) 164:6166-73. doi: 10.4049/jimmunol.164.12.6166

38. Houser BL, Tilburgs T, Hill J, Nicotra ML, Strominger JL. Two unique human decidual macrophage populations. J Immunol. (2011) 186:2633-42. doi: 10.4049/jimmunol.1003153

39. Svensson J, Jenmalm MC, Matussek A, Geffers R, Berg G, Ernerudh J. Macrophages at the fetal-maternal interface express markers of alternative activation and are induced by M-CSF and IL-10. J Immunol. (2011) 187:3671-82. doi: 10.4049/jimmunol.1100130

40. Jaiswal MK, Mallers TM, Larsen B, Kwak-Kim J, Chaouat G, GilmanSachs A, et al. V-ATPase upregulation during early pregnancy: a possible link to establishment of an inflammatory response during preimplantation period of pregnancy. Reproduction. (2012) 143:713-25. doi: 10.1530/rep12-0036

41. Mor G, Cardenas I, Abrahams V, Guller S. Inflammation and pregnancy: the role of the immune system at the implantation site. Ann N Y Acad Sci. (2011) 1221:80-7. doi: 10.1111/j.1749-6632.2010.05938.x

42. Gustafsson C, Mjosberg J, Matussek A, Geffers R, Matthiesen L, Berg $\mathrm{G}$, et al. Gene expression profiling of human decidual macrophages: evidence for immunosuppressive phenotype. PLoS ONE. (2008) 3:e2078. doi: 10.1371/journal.pone.0002078

43. Kammerer U, Eggert AO, Kapp M, McLellan AD, Geijtenbeek TB, Dietl J, et al. Unique appearance of proliferating antigen-presenting cells expressing DC-SIGN (CD209) in the decidua of early human pregnancy. Am J Pathol. (2003) 162:887-96. doi: 10.1016/s0002-9440(10) 63884-9

44. Laskarin G, Cupurdija K, Tokmadzic VS, Dorcic D, Dupor J, Juretic $\mathrm{K}$, et al. The presence of functional mannose receptor on macrophages at the maternal-fetal interface. Hum Reprod. (2005) 20:1057-66. doi: 10.1093/humrep/deh740

45. Xu Y, Romero R, Miller D, Kadam L, Mial TN, Plazyo O, et al. An M1like macrophage polarization in decidual tissue during spontaneous preterm labor that is attenuated by rosiglitazone treatment. I Immunol. (2016) 196:2476-91. doi: 10.4049/jimmunol.1502055 
46. Wang H, He M, Hou Y, Chen S, Zhang X, Zhang M, et al. Role of decidual CD14(+) macrophages in the homeostasis of maternal-fetal interface and the differentiation capacity of the cells during pregnancy and parturition. Placenta. (2016) 38:76-83. doi: 10.1016/j.placenta.2015.12.001

47. Pavlov O, Pavlova O, Ailamazyan E, Selkov S. Characterization of cytokine production by human term placenta macrophages in vitro. Am J Reprod Immunol. (2008) 60:556-67. doi: 10.1111/j.1600-0897.2008.00657.x

48. Osman I, Young A, Ledingham MA, Thomson AJ, Jordan F, Greer IA, et al. Leukocyte density and pro-inflammatory cytokine expression in human fetal membranes, decidua, cervix and myometrium before and during labour at term. Mol Hum Reprod. (2003) 9:41-5. doi: 10.1093/molehr/gag001

49. Phillippe M. Cell-free fetal DNA-a trigger for parturition. $N$ Engl J Med. (2014) 370:2534-6. doi: 10.1056/NEJMcibr1404324

50. Care AS, Diener KR, Jasper MJ, Brown HM, Ingman WV, Robertson SA. Macrophages regulate corpus luteum development during embryo implantation in mice. J Clin Invest. (2013) 123:3472-87. doi: $10.1172 /$ jci60561

51. Co EC, Gormley M, Kapidzic M, Rosen DB, Scott MA, Stolp HA, et al. Maternal decidual macrophages inhibit NK cell killing of invasive cytotrophoblasts during human pregnancy. Biol Reprod. (2013) 88:155. doi: 10.1095/biolreprod.112.099465

52. Erlebacher A. Immunology of the maternal-fetal interface. Annu Rev Immunol. (2013) 31:387-411. doi: 10.1146/annurev-immunol-032712-100003

53. Nagamatsu T, Schust DJ. The immunomodulatory roles of macrophages at the maternal-fetal interface. Reprod Sci. (2010) 17:209-18. doi: $10.1177 / 1933719109349962$

54. Sharma S, Godbole G, Modi D. Decidual control of trophoblast invasion. Am J Reprod Immunol. (2016) 75:341-50. doi: 10.1111/aji.12466

55. Fontana VA, Sanchez M, Cebral E, Calvo JC. Interleukin-1 beta regulates metalloproteinase activity and leptin secretion in a cytotrophoblast model. Biocell. (2010) 34:37-43. Available online at: https://www.mendoza.conicet. gov.ar/portal//biocell/vol/pdf/34_1/05.pdf

56. Lee CL, Guo Y, So KH, Vijayan M, Guo Y, Wong VH, et al. Soluble human leukocyte antigen G5 polarizes differentiation of macrophages toward a decidual macrophage-like phenotype. Hum Reprod. (2015) 30:2263-74. doi: 10.1093/humrep/dev196

57. Clark DE, Smith SK, Licence D, Evans AL, Charnock-Jones DS. Comparison of expression patterns for placenta growth factor, vascular endothelial growth factor (VEGF), VEGF-B and VEGF-C in the human placenta throughout gestation. J Endocrinol. (1998) 159:459-67. doi: 10.1677/joe.0.1590459

58. Kumazaki K, Nakayama M, Suehara N, Wada Y. Expression of vascular endothelial growth factor, placental growth factor, and their receptors Flt1 and KDR in human placenta under pathologic conditions. Hum Pathol. (2002) 33:1069-77. doi: 10.1053/hupa.2002.129420

59. Tan W, Chen L, Guo L, Ou X, Xie D, Quan S. Relationship between macrophages in mouse uteri and angiogenesis in endometrium during the peri-implantation period. Theriogenology. (2014) 82:1021-7. doi: 10.1016/j.theriogenology.2014.07.025

60. Lockwood CJ, Huang SJ, Krikun G, Caze R, Rahman M, Buchwalder LF, et al. Decidual hemostasis, inflammation, and angiogenesis in preeclampsia. Semin Thromb Hemost. (2011) 37:158-64. doi: 10.1055/s-0030-12 70344

61. Wheeler KC, Jena MK, Pradhan BS, Nayak N, Das S, Hsu CD, et al. VEGF may contribute to macrophage recruitment and M2 polarization in the decidua. PLoS ONE. (2018) 13:e0191040. doi: 10.1371/journal.pone.0191040

62. Lee MC, Wei SC, Tsai-Wu JJ, Wu CH, Tsao PN. Novel PKC signaling is required for LPS-induced soluble Flt-1 expression in macrophages. J Leukoc Biol. (2008) 84:835-41. doi: 10.1189/jlb.1007691

63. Ha CT, Wu JA, Irmak S, Lisboa FA, Dizon AM, Warren JW, et al. Human pregnancy specific beta-1-glycoprotein 1 (PSG1) has a potential role in placental vascular morphogenesis. Biol Reprod. (2010) 83:27-35. doi: 10.1095/biolreprod.109.082412

64. Blois SM, Tirado-Gonzalez I, Wu J, Barrientos G, Johnson B, Warren J, et al. Early expression of pregnancy-specific glycoprotein 22 (PSG22) by trophoblast cells modulates angiogenesis in mice. Biol Reprod. (2012) 86:191. doi: 10.1095/biolreprod.111.098251
65. Abrahams VM, Kim YM, Straszewski SL, Romero R, Mor G. Macrophages and apoptotic cell clearance during pregnancy. Am J Reprod Immunol. (2004) 51:275-82. doi: 10.1111/j.1600-0897.2004.00156.x

66. Abumaree MH, Chamley LW, Badri M, El-Muzaini MF. Trophoblast debris modulates the expression of immune proteins in macrophages: a key to maternal tolerance of the fetal allograft? J Reprod Immunol. (2012) 94:13141. doi: 10.1016/j.jri.2012.03.488

67. Hazan AD, Smith SD, Jones RL, Whittle W, Lye SJ, Dunk CE. Vascular-leukocyte interactions: mechanisms of human decidual spiral artery remodeling in vitro. Am J Pathol. (2010) 177:1017-30. doi: 10.2353/ajpath.2010.091105

68. Lash GE, Pitman H, Morgan HL, Innes BA, Agwu CN, Bulmer JN. Decidual macrophages: key regulators of vascular remodeling in human pregnancy. $J$ Leukoc Biol. (2016) 100:315-25. doi: 10.1189/jlb.1A0815-351R

69. Aldo PB, Racicot K, Craviero V, Guller S, Romero R, Mor G. Trophoblast induces monocyte differentiation into CD14+/CD16+ macrophages. Am J Reprod Immunol. (2014) 72:270-84. doi: 10.1111/aji.12288

70. Chabtini L, Mfarrej B, Mounayar M, Zhu B, Batal I, Dakle PJ, et al. TIM-3 regulates innate immune cells to induce fetomaternal tolerance. J Immunol. (2013) 190:88-96. doi: 10.4049/jimmunol.1202176

71. Wu ZM, Yang H, Li M, Yeh CC, Schatz F, Lockwood CJ, et al. Proinflammatory cytokine-stimulated first trimester decidual cells enhance macrophage-induced apoptosis of extravillous trophoblasts. Placenta. (2012) 33:188-94. doi: 10.1016/j.placenta.2011.12.007

72. Petroff MG, Sedlmayr P, Azzola D, Hunt JS. Decidual macrophages are potentially susceptible to inhibition by class Ia and class Ib HLA molecules. $J$ Reprod Immunol. (2002) 56:3-17. doi: 10.1016/S0165-0378(02)00024-4

73. Jetten N, Verbruggen S, Gijbels MJ, Post MJ, De Winther MP, Donners MM. Anti-inflammatory M2, but not pro-inflammatory M1 macrophages promote angiogenesis in vivo. Angiogenesis. (2014) 17:109-18. doi: 10.1007/s10456-013-9381-6

74. Shih SC, Mullen A, Abrams K, Mukhopadhyay D, Claffey KP. Role of protein kinase $\mathrm{C}$ isoforms in phorbol ester-induced vascular endothelial growth factor expression in human glioblastoma cells. J Biol Chem. (1999) 274:15407-14. doi: 10.1074/jbc.274.22.15407

75. Hoshi S, Nomoto K, Kuromitsu J, Tomari S, Nagata M. High glucose induced VEGF expression via PKC and ERK in glomerular podocytes. Biochem Biophys Res Commun. (2002) 290:177-84. doi: 10.1006/bbrc.2001.6138

76. Thompson JA, Grunert F, Zimmermann W. Carcinoembryonic antigen gene family: molecular biology and clinical perspectives. J Clin Lab Anal. (1991) 5:344-66. doi: 10.1002/jcla.1860050510

77. Lin TM, Halbert SP, Spellacy WN. Measurement of pregnancy-associated plasma proteins during human gestation. J Clin Invest. (1974) 54:576-82. doi: $10.1172 /$ jci107794

78. Straszewski-Chavez SL, Abrahams VM, Mor G. The role of apoptosis in the regulation of trophoblast survival and differentiation during pregnancy. Endocr Rev. (2005) 26:877-97. doi: 10.1210/er.2005-0003

79. Voll RE, Herrmann M, Roth EA, Stach C, Kalden JR, Girkontaite I. Immunosuppressive effects of apoptotic cells. Nature. (1997) 390:350-1. doi: $10.1038 / 37022$

80. DeKruyff RH, Bu X, Ballesteros A, Santiago C, Chim YL, Lee HH, et al. T cell/transmembrane, Ig, and mucin-3 allelic variants differentially recognize phosphatidylserine and mediate phagocytosis of apoptotic cells. J Immunol. (2010) 184:1918-30. doi: 10.4049/jimmunol.0 903059

81. Takahashi K, Naito M, Katabuchi H, Higashi K. Development, differentiation, and maturation of macrophages in the chorionic villi of mouse placenta with special reference to the origin of Hofbauer cells. $J$ Leukoc Biol. (1991) 50:57-68. doi: 10.1002/jlb.50.1.57

82. Loegl J, Hiden U, Nussbaumer E, Schliefsteiner C, Cvitic S, Lang $\mathrm{I}$, et al. Hofbauer cells of M2a, M2b and M2c polarization may regulate feto-placental angiogenesis. Reproduction. (2016) 152:447-55. doi: 10.1530/rep-16-0159

83. Ingman $\mathrm{K}$, Cookson VJ, Jones CJ, Aplin JD. Characterisation of Hofbauer cells in first and second trimester placenta: incidence, phenotype, survival in vitro and motility. Placenta. (2010) 31:535-44. doi: $10.1016 /$ j.placenta.2010.03.003 
84. Tang Z, Niven-Fairchild T, Tadesse S, Norwitz ER, Buhimschi CS, Buhimschi IA, et al. Glucocorticoids enhance CD163 expression in placental Hofbauer cells. Endocrinology. (2013) 154:471-82. doi: 10.1210/en.2012-1575

85. Bockle BC, Solder E, Kind S, Romani N, Sepp NT. DC-sign+ CD163+ macrophages expressing hyaluronan receptor LYVE-1 are located within chorion villi of the placenta. Placenta. (2008) 29:187-92. doi: 10.1016/j.placenta.2007.11.003

86. Joerink M, Rindsjo E, van Riel B, Alm J, Papadogiannakis N. Placental macrophage (Hofbauer cell) polarization is independent of maternal allergen-sensitization and presence of chorioamnionitis. Placenta. (2011) 32:380-5. doi: 10.1016/j.placenta.2011.02.003

87. Kim SY, Romero R, Tarca AL, Bhatti G, Kim CJ, Lee J, et al. Methylome of fetal and maternal monocytes and macrophages at the feto-maternal interface. Am J Reprod Immunol. (2012) 68:8-27. doi: 10.1111/j.1600-0897.2012.01108.x

88. Demir R, Erbengi T. Some new findings about Hofbauer cells in the chorionic villi of the human placenta. Acta Anat. (1984) 119:18-26. doi: $10.1159 / 000145857$

89. Christiansen $O B$. Recurrent miscarriage is a useful and valid clinical concept. Acta Obstet Gynecol Scand. (2014) 93:852-7. doi: 10.1111/aogs.12456

90. Listed N. Who: recommended definitions, terminology and format for statistical tables related to the perinatal period and use of a new certificate for cause of perinatal deaths. Acta Obstet Gynecol Scand. (1977) 56:247-53. doi: 10.3109/00016347709162009

91. Santos TDS, Ieque AL, de Carvalho HC, Sell AM, Lonardoni MVC, Demarchi IG, et al. Antiphospholipid syndrome and recurrent miscarriage: a systematic review and meta-analysis. J Reprod Immunol. (2017) 123:78-87.doi: 10.1016/j.jri.2017.09.007

92. Radovic JD, Popovic J, Krstic M, Tubic-Pavlovic A, Stefanovic M, Pop-Trajkovic S. The structure of immunocompetent decidual cells in recurrent missed abortions. Vojnosanitetski Pregled. (2016) 73:306-11. doi: 10.2298/VSP141226018R

93. Kang X, Zhang X, Zhao A. Macrophage depletion and TNF-alpha inhibition prevent resorption in CBA/J $\mathrm{x}$ DBA/2 model of CpGinduced abortion. Biochem Biophys Res Commun. (2016) 469:704-10. doi: 10.1016/j.bbrc.2015.12.024

94. Nakanishi T, Ozaki Y, Blomgren K, Tateyama H, Sugiura-Ogasawara M, Suzumori K. Role of cathepsins and cystatins in patients with recurrent miscarriage. Mol Hum Reprod. (2005) 11:351-5. doi: 10.1093/molehr/gah172

95. Goto S, Ozaki Y, Suzumori N, Yasukochi A, Kawakubo T, Furuno $\mathrm{T}$, et al. Role of cathepsin $\mathrm{E}$ in decidual macrophage of patients with recurrent miscarriage. Mol Hum Reprod. (2014) 20:454-62. doi: 10.1093/molehr/gau008

96. Tsao FY, Wu MY, Chang YL, Wu CT, Ho HN. M1 macrophages decrease in the deciduae from normal pregnancies but not from spontaneous abortions or unexplained recurrent spontaneous abortions. J Formos Med Assoc. (2017) 117:204-11. doi: 10.1016/j.jfma.2017.03.011

97. Jaiswal MK, Gilman-Sachs A, Chaouat G, Beaman KD. Placental ATPase expression is a link between multiple causes of spontaneous abortion in mice. Biol Reprod. (2011) 85:626-34. doi: 10.1095/biolreprod.111.092494

98. Wang WJ, Hao CF, Lin QD. Dysregulation of macrophage activation by decidual regulatory $\mathrm{T}$ cells in unexplained recurrent miscarriage patients. J Reprod Immunol. (2011) 92:97-102. doi: 10.1016/j.jri.2011. 08.004

99. Piao L, Chen CP, Yeh CC, Basar M, Masch R, Cheng YC, et al. Chinese herbal medicine for miscarriage affects decidual micro-environment and fetal growth. Placenta. (2015) 36:559-66. doi: 10.1016/j.placenta.2015. 02.006

100. Tontonoz P, Spiegelman BM. Fat and beyond: the diverse biology of PPARgamma. Annu Rev Biochem. (2008) 77:289-312. doi: 10.1146/annurev.biochem.77.061307.091829

101. Kolben TM, Rogatsch E, Vattai A, Hester A, Kuhn C, Schmoeckel $\mathrm{E}$, et al. PPARgamma expression is diminished in macrophages of recurrent miscarriage placentas. Int J Mol Sci. (2018) 19:E1872. doi: 10.3390/ijms19071872

102. Fock V, Mairhofer M, Otti GR, Hiden U, Spittler A, Zeisler H, et al. Macrophage-derived IL-33 is a critical factor for placental growth. $J$ Immunol. (2013) 191:3734-43. doi: 10.4049/jimmunol.1300490
103. Sheng YR, Hu WT, Wei CY, Tang LL, Liu YK, Liu YY, et al. IL-33/ST2 axis affects the polarization and efferocytosis of decidual macrophages in early pregnancy. Am J Reprod Immunol. (2018) 79:e12836. doi: 10.1111/aji.12836

104. Meng YH, Zhou WJ, Jin LP, Liu LB, Chang KK, Mei J, et al. RANKL-mediated harmonious dialogue between fetus and mother guarantees smooth gestation by inducing decidual M2 macrophage polarization. Cell Death Dis. (2017) 8:e3105. doi: 10.1038/cddis.2017.505

105. Sibai BM. Diagnosis and management of gestational hypertension and preeclampsia. Obstet Gynecol. (2003) 102:181-92. doi: 10.1016/S0029-7844(03)00475-7

106. Mol BWJ, Roberts CT, Thangaratinam S, Magee LA, de Groot CJM, Hofmeyr GJ. Pre-eclampsia. Lancet. (2016) 387:999-1011. doi: 10.1016/s0140-6736(15)00070-7

107. Williams PJ, Bulmer JN, Searle RF, Innes BA, Robson SC. Altered decidual leucocyte populations in the placental bed in pre-eclampsia and foetal growth restriction: a comparison with late normal pregnancy. Reproduction. (2009) 138:177-84. doi: 10.1530/rep-09-0007

108. Burk MR, Troeger C, Brinkhaus R, Holzgreve W, Hahn S. Severely reduced presence of tissue macrophages in the basal plate of pre-eclamptic placentae. Placenta. (2001) 22:309-16. doi: 10.1053/plac.2001.0624

109. Huang S, Zenclussen AC, Chen CP, Basar M, Yang H, Arcuri F, et al. The implication of aberrant GM-CSF expression in decidual cells in the pathogenesis of preeclampsia. Am J Pathol. (2010) 177:2472-82. doi: 10.2353/ajpath.2010.091247

110. Li M, Piao L, Chen CP, Wu X, Yeh CC, Masch R, et al. Modulation of decidual macrophage polarization by macrophage colony-stimulating factor derived from first-trimester decidual cells: implication in preeclampsia. Am J Pathol. (2016) 186:1258-66. doi: 10.1016/j.jpath.2015.12.021

111. Reister F, Frank HG, Kingdom JC, Heyl W, Kaufmann P, Rath W, et al. Macrophage-induced apoptosis limits endovascular trophoblast invasion in the uterine wall of preeclamptic women. Lab Invest. (2001) 81:1143-52. doi: 10.1038/labinvest.3780326

112. Tang Z, Buhimschi IA, Buhimschi CS, Tadesse S, Norwitz E, Niven-Fairchild $\mathrm{T}$, et al. Decreased levels of folate receptor-beta and reduced numbers of fetal macrophages (Hofbauer cells) in placentas from pregnancies with severe pre-eclampsia. Am J Reprod Immunol. (2013) 70:104-15. doi: 10.1111/ aji.12112

113. Yang SW, Cho EH, Choi SY, Lee YK, Park JH, Kim MK, et al. DCSIGN expression in Hofbauer cells may play an important role in immune tolerance in fetal chorionic villi during the development of preeclampsia. $J$ Reprod Immunol. (2017) 124:30-7. doi: 10.1016/j.jri.2017.09.012

114. Sharma A, Satyam A, Sharma JB. Leptin, IL-10 and inflammatory markers (TNF-alpha, IL-6 and IL-8) in pre-eclamptic, normotensive pregnant and healthy non-pregnant women. Am J Reprod Immunol. (2007) 58:21-30. doi: $10.1111 / j .1600-0897.2007 .00486 . x$

115. Abumaree MH, Al Jumah MA, Kalionis B, Jawdat D, Al Khaldi A, Abomaray FM, et al. Human placental mesenchymal stem cells (pMSCs) play a role as immune suppressive cells by shifting macrophage differentiation from inflammatory M1 to anti-inflammatory M2 macrophages. Stem Cell Rev. (2013) 9:620-41. doi: 10.1007/s12015-013-9455-2

116. Pianta S, Magatti M, Vertua E, Bonassi Signoroni P, Muradore I, Nuzzo AM, et al. Amniotic mesenchymal cells from pre-eclamptic placentae maintain immunomodulatory features as healthy controls. J Cell Mol Med. (2016) 20:157-69. doi: 10.1111/jcmm.12715

117. Zhao G, Miao H, Li X, Chen S, Hu Y, Wang Z, et al. TGF-beta3induced miR-494 inhibits macrophage polarization via suppressing PGE2 secretion in mesenchymal stem cells. FEBS Lett. (2016) 590:1602-13. doi: 10.1002/1873-3468.12200

118. Zheng YH, Deng YY, Lai W, Zheng SY, Bian HN, Liu ZA, et al. Effect of bone marrow mesenchymal stem cells on the polarization of macrophages. Mol Med Rep. (2018) 17:4449-59. doi: 10.3892/mmr.2018.8457

119. Magatti M, Caruso M, De Munari S, Vertua E, De D, Manuelpillai $\mathrm{U}$, et al. Human amniotic membrane-derived mesenchymal and epithelial cells exert different effects on monocyte-derived dendritic cell differentiation and function. Cell Transplant. (2015) 24:1733-52. doi: $10.3727 / 096368914 \times 684033$

120. Renaud SJ, Postovit LM, Macdonald-Goodfellow SK, McDonald GT, Caldwell JD, Graham CH. Activated macrophages inhibit human 
cytotrophoblast invasiveness in vitro. Biol Reprod. (2005) 73:237-43. doi: 10.1095/biolreprod.104.038000

121. Renaud SJ, Macdonald-Goodfellow SK, Graham CH. Coordinated regulation of human trophoblast invasiveness by macrophages and interleukin 10. Biol Reprod. (2007) 76:448-54. doi: 10.1095/biolreprod.106.055376

122. Lockwood CJ, Basar M, Kayisli UA, Guzeloglu-Kayisli O, Murk W, Wang J, et al. Interferon-gamma protects first-trimester decidual cells against aberrant matrix metalloproteinases 1,3 , and 9 expression in preeclampsia. Am J Pathol. (2014) 184:2549-59. doi: 10.1016/j.ajpath.2014.05.025

123. Minas V, Jeschke U, Kalantaridou SN, Richter DU, Reimer T, Mylonas I, et al. Abortion is associated with increased expression of FasL in decidual leukocytes and apoptosis of extravillous trophoblasts: a role for CRH and urocortin. Mol Hum Reprod. (2007) 13:663-73. doi: 10.1093/molehr/gam054

124. Straszewski-Chavez SL, Abrahams VM, Funai EF, Mor G. X-linked inhibitor of apoptosis (XIAP) confers human trophoblast cell resistance to Fas-mediated apoptosis. Mol Hum Reprod. (2004) 10:33-41. doi: 10.1093/molehr/gah001

125. Spradley FT, Palei AC, Granger JP. Immune mechanisms linking obesity and preeclampsia. Biomolecules. (2015) 5:3142-76. doi: 10.3390/biom5043142

126. Reister F, Frank HG, Heyl W, Kosanke G, Huppertz B, Schroder W, et al. The distribution of macrophages in spiral arteries of the placental bed in preeclampsia differs from that in healthy patients. Placenta. (1999) 20:229-33. doi: $10.1053 /$ plac. 1998.0373

127. Spaans F, Melgert BN, Chiang C, Borghuis T, Klok PA, de Vos P, et al. Extracellular ATP decreases trophoblast invasion, spiral artery remodeling and immune cells in the mesometrial triangle in pregnant rats. Placenta. (2014) 35:587-95. doi: 10.1016/j.placenta.2014.05.013

128. Liu L, Oza S, Hogan D, Perin J, Rudan I, Lawn JE, et al. Global, regional, and national causes of child mortality in 2000-13, with projections to inform post-2015 priorities: an updated systematic analysis. Lancet. (2015) 385:430-40. doi: 10.1016/s0140-6736(14)61698-6

129. Smid MC, Stringer EM, Stringer JS. A Worldwide epidemic: the problem and challenges of preterm birth in low- and middle-income countries. Am J Perinatol. (2016) 33:276-89. doi: 10.1055/s-0035-1571199

130. Petraglia F, Arcuri F, de Ziegler D, Chapron C. Inflammation: a link between endometriosis and preterm birth. Fertil Steril. (2012) 98:36-40. doi: 10.1016/j.fertnstert.2012.04.051

131. Dubicke A, Ekman-Ordeberg G, Mazurek P, Miller L, Yellon SM. Density of stromal cells and macrophages associated with collagen remodeling in the human cervix in preterm and term birth. Reprod Sci. (2016) 23:595-603. doi: $10.1177 / 1933719115616497$
132. Thaxton JE, Romero R, Sharma S. TLR9 activation coupled to IL10 deficiency induces adverse pregnancy outcomes. J Immunol. (2009) 183:1144-54. doi: 10.4049/jimmunol.0900788

133. Gonzalez JM, Dong Z, Romero R, Girardi G. Cervical remodeling/ripening at term and preterm delivery: the same mechanism initiated by different mediators and different effector cells. PLoS ONE. (2011) 6:e26877. doi: 10.1371/journal.pone.0026877

134. Fujiwara H, Araki Y, Imakawa K, Saito S, Daikoku T, Shigeta M, et al. Dual positive regulation of embryo implantation by endocrine and immune systems-step-by-step maternal recognition of the developing embryo. Am J Reprod Immunol. (2016) 75:281-9. doi: 10.1111/aji. 12478

135. Jaiswal MK, Agrawal V, Mallers T, Gilman-Sachs A, Hirsch E, Beaman KD. Regulation of apoptosis and innate immune stimuli in inflammation-induced preterm labor. J Immunol. (2013) 191:5702-13. doi: 10.4049/jimmunol.1301604

136. Wang YC, He F, Feng F, Liu XW, Dong GY, Qin HY, et al. Notch signaling determines the M1 versus M2 polarization of macrophages in antitumor immune responses. Cancer Res. (2010) 70:4840-9. doi: 10.1158/0008-5472.can-10-0269

137. Agrawal V, Jaiswal MK, Pamarthy S, Katara GK, Kulshrestha A, Gilman-Sachs A, et al. Role of Notch signaling during lipopolysaccharide-induced preterm labor. J Leukoc Biol. (2016) 100:261-74. doi: 10.1189/jlb.3HI0515-200RR

138. Rogers NM, Ferenbach DA, Isenberg JS, Thomson AW, Hughes J. Dendritic cells and macrophages in the kidney: a spectrum of good and evil. Nat Rev Nephrol. (2014) 10:625-43. doi: 10.1038/nrneph.2014.170

139. Coyne CB, Lazear HM. Zika virus - reigniting the TORCH. Nat Rev Microbiol. (2016) 14:707-15. doi: 10.1038/nrmicro.2016.125

Conflict of Interest Statement: The authors declare that the research was conducted in the absence of any commercial or financial relationships that could be construed as a potential conflict of interest.

Copyright (c) 2019 Yao, Xu and Jin. This is an open-access article distributed under the terms of the Creative Commons Attribution License (CC BY). The use, distribution or reproduction in other forums is permitted, provided the original author(s) and the copyright owner(s) are credited and that the original publication in this journal is cited, in accordance with accepted academic practice. No use, distribution or reproduction is permitted which does not comply with these terms. 